\title{
Influence of chelation on the Fenton-based electrochemical degradation of herbicide tebuthiuron
}

\author{
Fábio Gozzi $^{\mathrm{a}}$, Ignasi Sirés ${ }^{\mathrm{b}, * *}$, Silvio César de Oliveira ${ }^{\mathrm{a}}$, Amílcar Machulek Jr. ${ }^{\text {a }}$, Enric Brillas ${ }^{\mathrm{b}, *}$ \\ a Instituto de Química (INQUI), Universidade Federal de Mato Grosso do Sul, Av. Senador Filinto Muller, 1555, Caixa postal 549, MS 79070-900, Campo Grande, Brazil \\ ${ }^{\mathrm{b}}$ Laboratori d'Electroquímica dels Materials i del Medi Ambient, Departament de Química Física, Facultat de Química, Universitat de Barcelona, Martí i Franquès 1-11, 08028, \\ Barcelona, Spain
}

\section{A R T I C L E I N F O}

Article history:

Available online $\mathrm{xxx}$

Handling Editor: Shane Snyder

Keywords:

Electrochemical oxidation

Electro-Fenton

Iron complexes

Photoelectro-Fenton

Oxidation products

Tebuthiuron

\begin{abstract}
A B S T R A C T
This study describes the performance of electro-Fenton (EF) and photoelectro-Fenton (PEF) processes to degrade the herbicide tebuthiuron (TBH) in $0.050 \mathrm{M} \mathrm{Na}_{2} \mathrm{SO}_{4}$ at $\mathrm{pH}=3.0$. Experiments were performed in an undivided cell equipped with a boron-doped diamond (BDD) or Pt anode and an air-diffusion cathode that produces $\mathrm{H}_{2} \mathrm{O}_{2}$. Physisorbed hydroxyl radicals $\left(\mathrm{M}\left({ }^{\bullet} \mathrm{OH}\right)\right.$ ) generated from water oxidation at the anode and/or free ${ }^{\bullet} \mathrm{OH}$ formed from Fenton's reaction acted as main oxidants. All processes became much more effective using a BDD anode because of the higher oxidation power of BDD $\left({ }^{\bullet} \mathrm{OH}\right)$. Sulfate and nitrate were the predominant ions released during TBH destruction. In both, EF and PEF treatments, two distinct kinetic regimes were observed, the first one corresponding to the oxidation of free $\mathrm{TBH}$ by ${ }^{\bullet} \mathrm{OH}$ and the second one to that of the $\mathrm{Fe}(\mathrm{III})-\mathrm{TBH}$ complex by $\mathrm{M}\left({ }^{\bullet} \mathrm{OH}\right)$. The effect of $\mathrm{Fe}^{2+}$ and $\mathrm{TBH}$ concentrations on the kinetics of both regions has been examined. Moreover, a poor mineralization was reached with Pt anode, whereas almost total mineralization was attained by EF and PEF with BDD. Both processes showed analogous mineralization rates because the intermediates produced could not be photodegraded by UVA light. Gas chromatography-mass spectrometry analysis of electrolyzed solutions revealed the generation of eight heteroaromatics along with 1,3-dimethylurea, which have been included in a reaction pathway proposed for the initial degradation of TBH.
\end{abstract}

\section{Introduction}

Agricultural wastewater is polluted with mixtures of commercial pesticides, which can attain contents as high as $500 \mathrm{mg} \mathrm{L}^{-1}$ (Chiron et al., 2000). Since many herbicides are largely consumed worldwide, they enter into water bodies and soil, where they accumulate over a long period under natural conditions (Rodrigo et al., 2014). These compounds are toxic to animals and human beings and hence, they should be removed from agricultural wastewater (Oturan et al., 2009; Rodrigo et al., 2014). Among these compounds, the thiadiazolylurea herbicide tebuthiuron (TBH, 1-(5-tert-butyl-1,3,4-thiadiazol-2-yl)-1,3-dimethylurea), $\mathrm{C}_{9} \mathrm{H}_{16} \mathrm{~N}_{4} \mathrm{OS}, \quad M=228.31 \mathrm{~g} \mathrm{~mol}^{-1}$ ) is widely used in central Brazil for controlling sugar cane cultivations (Silva et al., 2007). This chemical is inefficiently destroyed in wastewater treatment facilities and, as a result, it has been detected in natural water and wastewater (Ferracini et al., 2005; Diaz et al., 2008). TBH is highly soluble in water, being also found in soil treated with sugar cane vinasse (Lourencetti et al., 2008). Aiming to counteract its large recalcitrance, advanced oxidation processes (AOPs) like photo-Fenton (Nogueira et al., 2005; Silva et al., 2007, 2010) and $\mathrm{TiO}_{2}$

photo-

\footnotetext{
* Corresponding author.

* Corresponding author.

Email addresses: i.sires@ub.edu (I. Sirés); brillas@ub.edu (E. Brillas)
}

catalysis (Muneer et al., 2005; Bahnemann et al., 2007) have been utilized to degrade TBH aqueous solutions. In the AOPs, reactive oxygen species (ROS) like ${ }^{\bullet} \mathrm{OH}$ are produced on site. This radical is the second strongest oxidizing agent known, with $E^{\circ}\left({ }^{\circ} \mathrm{OH} / \mathrm{H}_{2} \mathrm{O}\right)=2.8 \mathrm{~V} /$ SHE, being able to attack most organic pollutants up to their overall mineralization (Brillas et al., 2009; Sirés et al., 2012). However, - OH destroys very slowly the Fe(III) complexes of organics. Silva et al. (2010) have shown that $\mathrm{Fe}^{3+}$ forms stable complexes with the thiadiazole ring of TBH since it acts as an electron donor, i.e., an electron-rich complexation agent. Consequently, chelation of $\mathrm{Fe}^{3+}$ by $\mathrm{TBH}$ is expected to hamper the herbicide degradation in Fenton-related treatments.

Over the last 15 years, the number of articles devoted to the treatment of organic pollutants by electrochemical AOPs (EAOPs) has been growing unceasingly (Brillas et al., 2009; Sirés et al., 2014; Martínez-Huitle et al., 2015; Moreira et al., 2017). The simplest and most known EAOP is the so-called anodic oxidation (AO), electrochemical oxidation or electrochemical incineration. This method allows the direct destruction of organics at the anode $\mathrm{M}$ and, more rapidly, their indirect reaction with adsorbed hydroxyl radicals $\left(\mathrm{M}\left({ }^{\bullet}\right.\right.$ $\mathrm{OH})$ ) originated from reaction (1) at high current (Boye et al., 2002; Marselli et al., 2003; Panizza and Cerisola, 2009). Active and non-active anodes show different performance in AO. Active anodes like Pt and DSA ${ }^{\circledR}$ accumulate small amounts of $\mathrm{M}\left({ }^{*} \mathrm{OH}\right)$ because this 
species is subsequently oxidized to the weaker oxidant MO that only causes the conversion of pollutants into persistent short-chain linear carboxylic acids (El-Ghenymy et al., 2014; Coria et al., 2016; Steter et al., 2016). In contrast, large amounts of the powerful oxidant $\mathrm{M}\left({ }^{\bullet} \mathrm{OH}\right)$ are formed over/near the surface of non-active anodes. Among them, boron-doped diamond (BDD) is preferred because it accumulates the greatest quantity of $\mathrm{M}\left({ }^{\bullet} \mathrm{OH}\right)$ due to its large $\mathrm{O}_{2}$-evolution overpotential and its weak BDD- ${ }^{-} \mathrm{OH}$ interaction, eventually leading to the mineralization of most organics, including refractory aliphatic carboxylic acids (Cañizares et al., 2005; Özcan et al., 2008; El-Ghenymy et al., 2013; dos Santos et al., 2015).

$$
\mathrm{M}+\mathrm{H}_{2} \mathrm{O} \rightarrow \mathrm{M}(\cdot \mathrm{OH})+\mathrm{H}^{+}+\mathrm{e}^{-}
$$

Other EAOPs involve the cathodic generation of $\mathrm{H}_{2} \mathrm{O}_{2}$ upon reduction of $\mathrm{O}_{2}$ gas via reaction (2). This is feasible at carbonaceous cathodes including carbon nanotubes (Khataee et al., 2013, 2014), carbon-polytetrafluoroethylene (PTFE) $\mathrm{O}_{2}$ - or air-diffusion electrodes (Thiam et al., 2015a,b; Coria et al., 2016; Lanzalaco et al., 2017), BDD (Cruz-González et al., 2012; Coria et al., 2015), activated carbon fiber (Wang et al., 2008), carbon felt (Dirany et al., 2012; El-Ghenymy et al., 2014) and reticulated vitreous carbon (Coria et al., 2015).

$$
\mathrm{O}_{2}(\mathrm{~g})+2 \mathrm{H}^{+}+2 \mathrm{e}^{-} \rightarrow \mathrm{H}_{2} \mathrm{O}_{2}
$$

When $\mathrm{H}_{2} \mathrm{O}_{2}$ is electrogenerated in a one-compartment cell, the process is so-called AO- $\mathrm{H}_{2} \mathrm{O}_{2}$ and organics can be oxidized by different ROS like $\mathrm{H}_{2} \mathrm{O}_{2}$ and hydroperoxyl radical $\left(\mathrm{HO}_{2}{ }^{*}\right)$ and, to much larger extent, by $\mathrm{M}\left({ }^{\circ} \mathrm{OH}\right)$ (Sirés et al., 2014). Addition of $\mathrm{Fe}^{2+}$ ion to the solution allows the production of ${ }^{\bullet} \mathrm{OH}$ in the bulk from Fenton's reaction (3) (Vasudevan and Oturan, 2014; Martínez-Huitle et al., 2015). This gives rise to the electro-Fenton (EF) process, with optimum $\mathrm{pH}$ near 3 for maximum ${ }^{*} \mathrm{OH}$ production and continuous cathodic $\mathrm{Fe}^{3+}$ reduction to $\mathrm{Fe}^{2+}$. A more powerful treatment is obtained under photoelectro-Fenton (PEF) conditions, once the solution is irradiated with UVA light that favors the production of more ${ }^{\bullet} \mathrm{OH}$ from photolytic reaction (4), as well as the photodecomposition of some Fe(III) complexes via reaction (5) (Wang et al., 2008; Brillas et al., 2009; Thiam et al., 2015b; Moreira et al., 2017).

$$
\begin{aligned}
& \mathrm{H}_{2} \mathrm{O}_{2}+\mathrm{Fe}^{2+} \rightarrow \mathrm{Fe}^{3+}+\cdot \mathrm{OH}+\mathrm{OH}^{-} \\
& \mathrm{Fe}(\mathrm{OH})^{2+}+h v \rightarrow \mathrm{Fe}^{2+}+\cdot \mathrm{OH} \\
& \mathrm{Fe}(\mathrm{OOCR})^{2+}+h v \rightarrow \mathrm{Fe}^{2+}+\mathrm{CO}_{2}+\mathrm{R}^{\bullet}
\end{aligned}
$$

Only a limited number of papers has been published regarding the degradation of TBH solutions by EAOPs. Alves et al. (2012a, b) treated $350-400 \mathrm{~mL}$ of $100 \mathrm{mg} \mathrm{L}^{-1}$ of this herbicide at $\mathrm{pH}$ near 1 and $20^{\circ} \mathrm{C}$ by $\mathrm{AO}$ with a DSA ${ }^{\circledR}$ or BDD anode. A pseudo-first-order kinetics was always found, with the rate constant for BDD being two-fold greater, in agreement with a mineralization of $13 \%$ for $\mathrm{DSA}^{\circledR}$ and $80 \%$ for BDD after $180 \mathrm{~min}$ of electrolysis at a current density $(j)$ of $200 \mathrm{~mA} \mathrm{~cm}^{-2}$.

In this work, we have studied the influence of $\mathrm{Fe}^{3+}$ chelation by $\mathrm{TBH}$ on the performance of EF and PEF processes using a BDD or Pt anode and a carbon-PTFE air-diffusion cathode. To do this, the herbicide abatement and TOC removal were comparatively determined by
AO- $\mathrm{H}_{2} \mathrm{O}_{2}$ and both Fenton-based EAOPs. The fate of released inorganic ions during TBH degradation was monitored to calculate the mineralization current efficiency (MCE) in each treatment. The effect of $\mathrm{Fe}^{2+}$ and herbicide concentrations on the performance of EF was assessed to obtain more information about $\mathrm{Fe}^{3+}$ chelation by $\mathrm{TBH}$. Finally, an initial degradation route has been proposed from the intermediates formed, as detected by gas chromatography-mass spectrometry (GC-MS).

\section{Experimental}

\subsection{Reagents}

Analytical grade TBH ( $>99 \%$ purity) and heptahydrated Fe(II) sulfate were supplied by Sigma-Aldrich. Supporting electrolytes like sodium sulfate and lithium perchlorate were of analytical grade purchased from Fluka. High-purity Millipore Milli-Q water (resistivity $>18 \mathrm{M} \Omega \mathrm{cm}$ ) was used for the preparation of all solutions. Their initial $\mathrm{pH}$ was adjusted to 3.0 with concentrated sulfuric acid of analytical grade purchased from Merck. All the other chemicals were of HPLC or analytical grade supplied by Merck, Panreac and Sigma-Aldrich.

\subsection{Electrolytic systems}

All treatments of TBH solutions were carried out with a volume of $100 \mathrm{~mL}$ in an undivided cell under stirring with a magnetic bar at $800 \mathrm{rpm}$. The solution temperature was kept at $25^{\circ} \mathrm{C}$ by recirculating thermostated water through a jacket. The anode was either a BDD thin-film electrode on a single-crystal $p$-type Si (100) wafer purchased from NeoCoat (La-Chaux-de-Fonds, Switzerland) or) a Pt sheet (99.99\% purity) from SEMPSA (Barcelona, Spain). The anode was connected to a carbon-PTFE air-diffusion cathode purchased from E-TEK (Somerset, NJ, USA) and placed at a distance of $1 \mathrm{~cm}$, as explained elsewhere (Thiam et al., 2015a; Guelfi et al., 2017). All electrodes had a geometric area of $3 \mathrm{~cm}^{2}$. The trials were performed at constant $j$ provided by an Amel 2049 potentiostat-galvanostat. EF and PEF were run by adding a small content of $\mathrm{Fe}^{2+}$ as catalyst (Sirés et al., 2014; Thiam et al., 2015a; Steter et al., 2016). The cathode accumulated $\mathrm{H}_{2} \mathrm{O}_{2}$ into the solution upon injection of compressed air at $1 \mathrm{~L} \mathrm{~min}^{-1}$ onto its dry face once the power supply was switched on (Brillas et al., 2009; Steter et al., 2016). In PEF, a Philips TL/6W/ 08 black light blue fluorescent was used to illuminate the solution with UVA light $\left(\lambda_{\max }=360 \mathrm{~nm}\right)$, which was placed at $7 \mathrm{~cm}$ above the solution surface. The irradiance was $5 \mathrm{Wm}^{-2}$, as determined with a Kipp\&Zonen CUV 5 UV radiometer.

\subsection{Analytical procedures}

The solution $\mathrm{pH}$ was measured with a Crison GLP $22 \mathrm{pH}-$ meter. The TBH decay was followed by reversed-phase high-performance liquid chromatography (HPLC) using a Waters system composed of a $600 \mathrm{LC}$ and a 996 photodiode array detector set at $\lambda=249 \mathrm{~nm}$. The samples were mixed with the same volume of acetonitrile to prevent further attack of oxidants onto the herbicide and its by-products. The aliquots were injected into the LC and eluted with 25:75 (v/v) acetonitrile/water at $0.6 \mathrm{~mL} \mathrm{~min}^{-1}$ through a Waters Spherisorb ODS2 $5 \mu \mathrm{m}$ $(150 \mathrm{~mm} \times 4.6 \mathrm{~mm}$ (i.d.) $)$ column at $40^{\circ} \mathrm{C}$. Linear aliphatic carboxylic acids did not appear upon sample analysis by ion-exclusion HPLC.

The solution TOC was measured directly by injecting $50 \mu \mathrm{L}$ aliquots into a Shimadzu VCSN TOC analyzer, with $\pm 1 \%$ accuracy. 
For the determination of the total nitrogen (TN), the analyzer was coupled to a Shimadzu TNM-1 unit. Trials to assess TBH decay and TOC removal were run in triplicate, being reported their average values. The standard deviation was $<4 \%$ in all cases.

The $\mathrm{NH}_{4}{ }^{+}$ion concentration was determined with an Alpkem Flow Solution IV flow injection system through the standard indophenol blue method (Bolleter et al., 1961). The $\mathrm{SO}_{4}{ }^{2-}$ and $\mathrm{NO}_{3}{ }^{-}$concentrations were found by ion chromatography using a Shimadzu 10 Avp system composed of an LC fitted with a Shim-Pack IC-A1S, $10 \mathrm{~cm} \times 4.6 \mathrm{~mm}$ (i.d.), column at $40^{\circ} \mathrm{C}$ and a conductivity detector. The mobile phase was a $2.4 \mathrm{mM}$ tris(hydroxymethyl) aminomethane and $2.6 \mathrm{mM}$ phthalic acid solution at $1.5 \mathrm{~mL} \mathrm{~min}^{-1}$.

Stable organic products originated after 4-5 min of $\mathrm{AO}-\mathrm{H}_{2} \mathrm{O}_{2}, \mathrm{EF}$ and PEF treatments of a $0.460 \mathrm{mM}$ TBH solution at $\mathrm{pH} 3.0$ using a BDD/air-diffusion cell at $j=100 \mathrm{~mA} \mathrm{~cm}^{-2}$ were: (i) extracted with $\mathrm{CH}_{2} \mathrm{Cl}_{2}$, dried over $\mathrm{Na}_{2} \mathrm{SO}_{4}$, filtered and concentrated to a final volume of about $2 \mathrm{~mL}$, or (ii) lyophilized and then dissolved with $2 \mathrm{~mL}$ $\mathrm{CH}_{2} \mathrm{Cl}_{2}$. GC-MS analysis of the organic solutions was performed with non-polar and polar columns (see details in Thiam et al. (2015b)).

\section{Results and discussion}

\subsection{Degradation of TBH solutions by EAOPs with BDD}

Electrolyses of $0.460 \mathrm{mM}$ herbicide solutions in $0.050 \mathrm{M} \mathrm{Na}_{2} \mathrm{SO}_{4}$ at $\mathrm{pH} 3.0$ were carried out with a BDD/air-diffusion cell by the three aforementioned EAOPs at $j=100 \mathrm{~mA} \mathrm{~cm}^{-2}$ for $540 \mathrm{~min}$. The solutions contained $0.50 \mathrm{mM} \mathrm{Fe}^{2+}$ as catalyst in the two Fenton-based electrochemical processes, chosen as the best concentration on the basis of similar treatments of other organics (El-Ghenymy et al., 2014; Sirés et al., 2014; Thiam et al., 2015a). Note that no significant $\mathrm{pH}$ variation was observed during these treatments.

Fig. 1a depicts a continuous but slow removal of the herbicide in AO- $\mathrm{H}_{2} \mathrm{O}_{2}$, showing total disappearance at $540 \mathrm{~min}$. This informs about the limited reactivity of TBH with the main oxidant BDD $\left({ }^{\circ} \mathrm{OH}\right)$ generated from reaction (1), since this is confined close to the BDD surface. In contrast, two consecutive degradation regimes were found in EF and PEF. Within the first stage, the herbicide underwent a very sharp decay of 30-35\%, whereupon its removal was decelerated until total disappearance was achieved at $240 \mathrm{~min}$. Such an enhancement of the degradation rate can be related to the effective attack of ${ }^{\bullet} \mathrm{OH}$ formed from Fenton's reaction (3) onto the herbicide. The change in reactivity with time can then be ascribed to the presence of two distinct electroactive species. At short time (first region), one can expect the fast oxidation of parent TBH mainly with homogeneous ${ }^{\bullet} \mathrm{OH}$, whereas at longer time (second region), BDD $\left({ }^{\bullet} \mathrm{OH}\right)$ and/or ${ }^{\bullet} \mathrm{OH}$ react more slowly with the more recalcitrant Fe(III)-TBH complex. The formation of this species was reported by Silva et al. (2010) in non-electrochemical Fenton systems and hence, it can become predominant in our cells once reached a large conversion of $\mathrm{Fe}^{2+}$ into $\mathrm{Fe}^{3+}$ from Fenton's reaction (3). Note that our previous works dealing with $N$-herbicides like propoxur (Guelfi et al., 2017) and S-metolachlor (Guelfi et al., 2018) also reported a dual kinetic behavior, with a fast decay followed by a slower abatement. In contrast, using the same type of electrolytic system to degrade aromatics without $N$-heteroatoms, a one-stage pseudo-first-order kinetics is always obtained for the corresponding $\mathrm{EF}$ and $\mathrm{PEF}$ treatments due to the absence of chelation (Brillas et al., 2009; Sirés et al., 2014).

Good linear correlations related to a pseudo-first-order kinetics were found for the single region in $\mathrm{AO}-\mathrm{H}_{2} \mathrm{O}_{2}$ and both regions in $\mathrm{EF}$ and PEF, as can be seen in the inset of Fig. 1a. The corresponding ap-

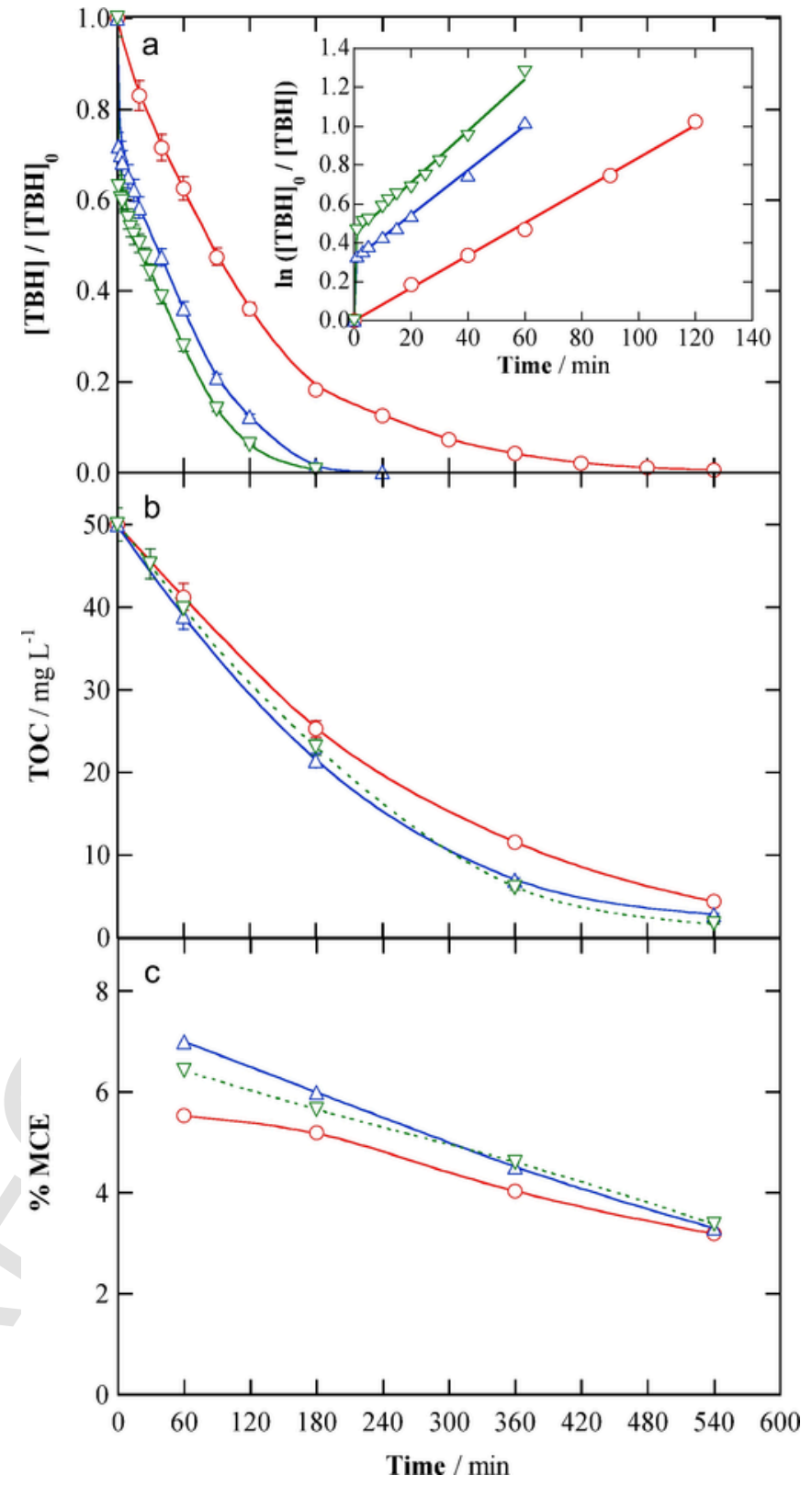

Fig. 1. Change of (a) normalized tebuthiuron concentration, (b) TOC and (c) mineralization current efficiency with electrolysis time for the degradation of $100 \mathrm{~mL}$ of $0.460 \mathrm{mM}$ herbicide solutions in $0.050 \mathrm{M} \mathrm{Na}_{2} \mathrm{SO}_{4}$ at $\mathrm{pH}=3.0$ and $25^{\circ} \mathrm{C}$ using a stirred boron-doped diamond (BDD)/air-diffusion cell at current density $(j)=100 \mathrm{~mA} \mathrm{~cm}^{-2}$. Method: $(\bigcirc)$ Anodic oxidation with electrogenerated $\mathrm{H}_{2} \mathrm{O}_{2}\left(\mathrm{AO}-\mathrm{H}_{2} \mathrm{O}_{2}\right),(\bigwedge)$ electro-Fenton (EF) with $0.50 \mathrm{mM} \mathrm{Fe}^{2+}$ and $(\nabla)$ photoelectro-Fenton (PEF) with $0.50 \mathrm{mM}$ $\mathrm{Fe}^{2+}$ under illumination with a $6 \mathrm{~W}$ UVA lamp. The inset in (a) shows the corresponding pseudo-first-order kinetic analysis.

parent rate constants $\left(k_{1}\right)$ are summarized in Table 1 . The $k_{1}$-value in the first region of EF and PEF was 40-fold and 56-fold higher, respectively, compared to $\mathrm{AO}-\mathrm{H}_{2} \mathrm{O}_{2}$, whereas that found in the second region was only 1.3- and 1.6-fold higher. This suggests that the complexed TBH (i.e., Fe(III)-TBH) is mainly oxidized by BDD $\left({ }^{\bullet} \mathrm{OH}\right)$ as occurs in $\mathrm{AO}-\mathrm{H}_{2} \mathrm{O}_{2}$, which is attributed to the fact that $\mathrm{Fe}(\mathrm{III})$ complexes are more refractory to homogeneous ${ }^{\bullet} \mathrm{OH}$ (Brillas et al., 2009). The greater $k_{1}$-values found in PEF compared to those in EF can be explained by the larger formation of $\bullet \mathrm{OH}$ from Fenton's reaction (3) induced by photolytic reaction (4), since blank trials demonstrated the 
Table 1

Pseudo-first-order rate constants, along with the $R$-squared, and percentages of TOC removal and mineralization current efficiency at $540 \mathrm{~min}$ for the degradation of $100 \mathrm{~mL}$ of tebuthiuron solutions in $0.050 \mathrm{M} \mathrm{Na}_{2} \mathrm{SO}_{4}$ at $\mathrm{pH}=3.0$ using an air-diffusion cathode and different anodes, all of $3 \mathrm{~cm}^{2}$ area, under selected conditions operating at $j=100 \mathrm{~mA} \mathrm{~cm}^{-2}$ and $25^{\circ} \mathrm{C}$

\begin{tabular}{|c|c|c|c|c|c|c|c|}
\hline Anode & Method & $\begin{array}{l}{[\mathrm{TBH}]_{0}} \\
(\mathrm{mM})\end{array}$ & $\begin{array}{l}{\left[\mathrm{Fe}^{2+}\right]} \\
(\mathrm{mM})\end{array}$ & $k_{1}\left(\min ^{-1}\right)$ & $R^{2}$ & $\begin{array}{l}\% \text { TOC } \\
\text { removal }\end{array}$ & $\begin{array}{l}\% \\
\mathrm{MCE}\end{array}$ \\
\hline \multirow[t]{9}{*}{ BDD } & \multirow{7}{*}{$\begin{array}{l}\mathrm{AO}- \\
\mathrm{H}_{2} \mathrm{O}_{2} \\
\mathrm{EF}\end{array}$} & 0.460 & - & $8.3 \times 10^{-3}$ & 0.997 & 91.2 & 3.4 \\
\hline & & 0.092 & 0.50 & $\begin{array}{l}1.3^{\mathrm{a}} \\
2.1 \times 10^{-2} \\
\mathrm{~b}\end{array}$ & $\begin{array}{c}0.980 \\
0.985\end{array}$ & $88.8^{c}$ & $1.1^{\mathrm{c}}$ \\
\hline & & 0.184 & 0.50 & $\begin{array}{l}0.93^{\mathrm{a}} \\
1.5 \times 10^{-2} \\
\mathrm{~b}\end{array}$ & $\begin{array}{c}0.975 \\
0.990\end{array}$ & $95.3^{d}$ & $1.5^{\mathrm{d}}$ \\
\hline & & 0.460 & 0.10 & $\begin{array}{l}0.12^{\mathrm{a}} \\
1.0 \times 10^{-2} \\
\mathrm{~b}\end{array}$ & $\begin{array}{c}0.997 \\
0.994\end{array}$ & 87.2 & 3.1 \\
\hline & & 0.460 & 0.50 & $\begin{array}{l}0.33^{\mathrm{a}} \\
1.1 \times 10^{-2} \\
\mathrm{~b}\end{array}$ & $\begin{array}{c}0.998 \\
0.997\end{array}$ & 94.4 & 3.3 \\
\hline & & 0.460 & 1.00 & $\begin{array}{l}0.83^{\mathrm{a}} \\
1.1 \times 10^{-2} \\
\mathrm{~b}\end{array}$ & $\begin{array}{c}0.998 \\
0.993\end{array}$ & 95.6 & 3.3 \\
\hline & & 0.460 & 1.50 & $\begin{array}{l}0.80^{\mathrm{a}} \\
1.1 \times 10^{-2} \\
\mathrm{~b}\end{array}$ & $\begin{array}{c}0.999 \\
0.985\end{array}$ & 96.6 & 3.4 \\
\hline & \multirow[t]{2}{*}{ PEF } & 0.460 & 0.50 & $\begin{array}{l}0.46^{\mathrm{a}} \\
1.3 \times 10^{-2} \\
\mathrm{~b}\end{array}$ & $\begin{array}{c}0.998 \\
0.991\end{array}$ & 96.6 & 3.4 \\
\hline & & 0.460 & 1.00 & $\begin{array}{l}0.79^{\mathrm{a}} \\
1.1 \times 10^{-2} \\
\mathrm{~b}\end{array}$ & $\begin{array}{c}0.997 \\
0.996\end{array}$ & 96.2 & 3.3 \\
\hline \multirow[t]{5}{*}{$\mathrm{Pt}$} & \multirow{4}{*}{$\begin{array}{l}\mathrm{AO}- \\
\mathrm{H}_{2} \mathrm{O}_{2} \\
\mathrm{EF}\end{array}$} & 0.460 & - & $3.5 \times 10^{-3}$ & 0.989 & 21.0 & 0.7 \\
\hline & & 0.460 & 0.50 & $\begin{array}{l}0.33^{\mathrm{a}} \\
1.4 \times 10^{-2} \\
\mathrm{~b}\end{array}$ & $\begin{array}{c}0.997 \\
0.995\end{array}$ & 60.0 & 2.1 \\
\hline & & 0.460 & 1.00 & $\begin{array}{l}0.43^{\mathrm{a}} \\
1.6 \times 10^{-2} \\
\mathrm{~b}\end{array}$ & $\begin{array}{c}0.998 \\
0.995\end{array}$ & 62.4 & 2.3 \\
\hline & & 0.460 & 1.50 & $\begin{array}{l}0.49^{\mathrm{a}} \\
1.7 \times 10^{-2} \\
\mathrm{~b}\end{array}$ & $\begin{array}{c}0.996 \\
0.992\end{array}$ & 74.4 & 2.6 \\
\hline & PEF & 0.460 & 0.50 & $\begin{array}{l}0.35^{\mathrm{a}} \\
1.5 \times 10^{-2} \\
\mathrm{~b}\end{array}$ & $\begin{array}{c}0.998 \\
0.988\end{array}$ & 63.5 & 2.2 \\
\hline
\end{tabular}

${ }^{a}$ Determined at short electrolysis times (first linear region).

b Determined at long electrolysis time (second linear region).

c At $300 \mathrm{~min}$

d At $480 \mathrm{~min}$.

photostability of TBH solutions in the absence and presence of $\mathrm{Fe}^{2+}$ under UVA illumination.

Fig. 1b highlights a regular TOC abatement in all treatments, as expected if organic molecules with a thiadiazole ring are quickly destroyed. TOC abatement was enhanced in the sequence $\mathrm{AO}-\mathrm{H}_{2} \mathrm{O}_{2}$ $<$ EF $\sim$ PEF. The mineralization rate of the two latter Fenton-based processes was quite similar, yielding a TOC reduction $>94 \%$ (see Table 1). A slightly lower TOC removal was achieved by $\mathrm{AO}-\mathrm{H}_{2} \mathrm{O}_{2}$, with a decay of about $91 \%$ at the same time. The slow TOC decay found in all EAOPs suggests that organic by-products were preferentially destroyed upon the action of $\operatorname{BDD}\left({ }^{\bullet} \mathrm{OH}\right)$ rather than ${ }^{*} \mathrm{OH}$, as expected if most of them were linear compounds that existed as Fe(III)-complexes. The limited photoactivity of all these species under UVA irradiation via reaction (5), as mentioned above for TBH, explains the similar trends found in EF and PEF.

\subsection{Fate of released inorganic ions and mineralization current efficiency}

In order to determine the inorganic ions released during the application of EAOPs, a $0.460 \mathrm{mM}$ TBH solution with $0.050 \mathrm{M} \mathrm{LiClO}_{4}$ as supporting electrolyte and $0.50 \mathrm{mM} \mathrm{Fe}^{2+}$ as catalyst at $\mathrm{pH} 3.0$ was treated by EF using the BDD/air-diffusion cell at $j=100 \mathrm{~mA} \mathrm{~cm}^{-2}$. As can be seen in Fig. 2a, TOC decreased gradually until a $94.5 \%$ mineralization was attained at $540 \mathrm{~min}$, mimicking the behavior found in $0.050 \mathrm{M} \mathrm{Na}_{2} \mathrm{SO}_{4}$ (Fig. 1b). This informs about the negligible influence of these electrolytes on TBH degradation, since $\mathrm{LiClO}_{4}$ is considered as electrochemically inert (Panizza and Cerisola, 2009). Fig. $2 \mathrm{a}$ also shows a continuous decay of $\mathrm{TN}$ during the $\mathrm{EF}$ treatment, from 1.840 to $1.053 \mathrm{mM}$, which means that a large proportion of the initial $\mathrm{N}(42.8 \%)$ was lost as $N$-volatile species, probably $\mathrm{N}_{2}$ and $\mathrm{NO}_{\mathrm{x}}$, as reported for other $N$-containing organic compounds (Guelfi et al., 2017; Moreira et al., 2017).

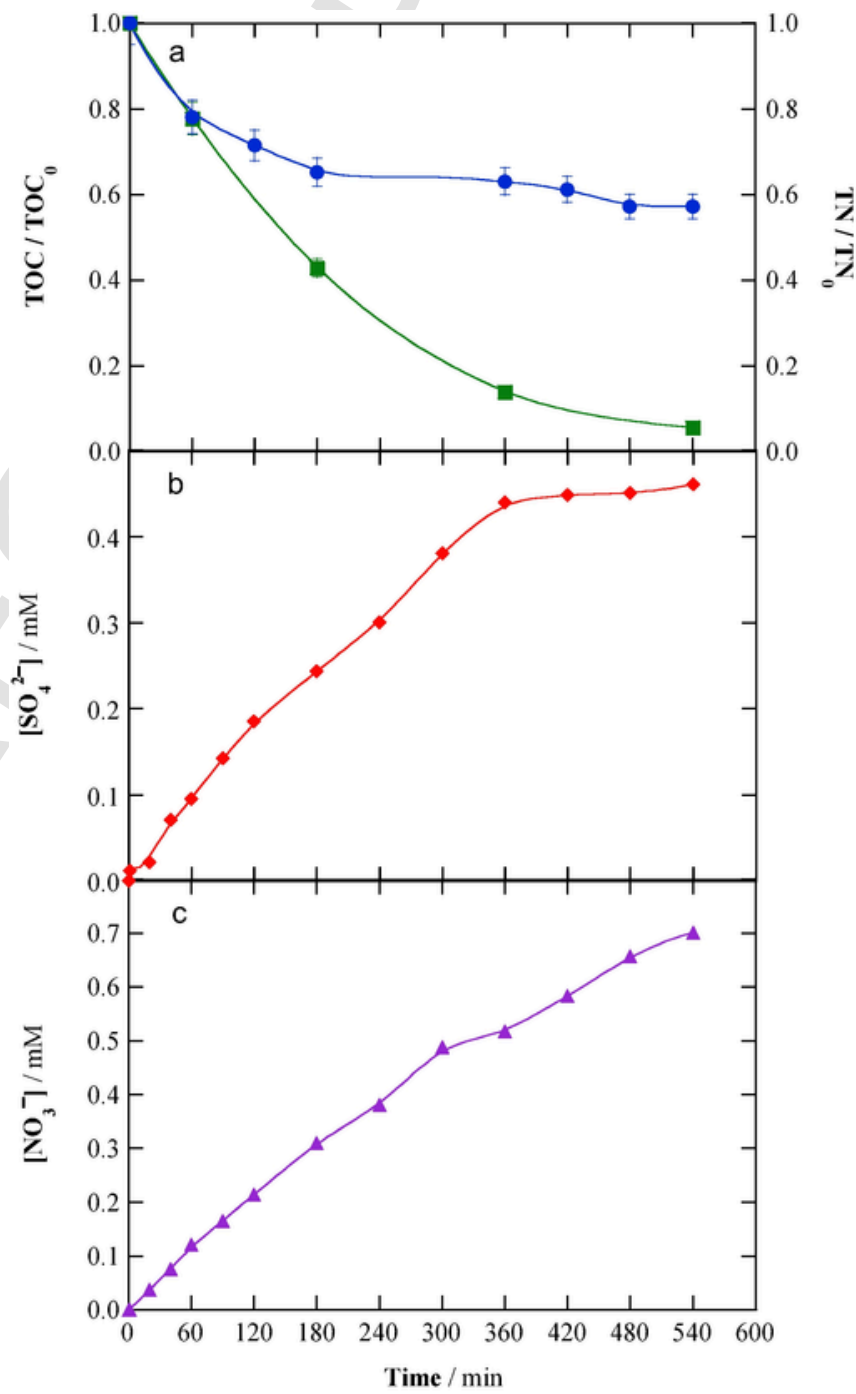

Fig. 2. Time course of (a) normalized ( ) TOC and $(\bigcirc)$ total nitrogen, and concentration of (b) (>) sulfate and (c) ( $)$ nitrate ions during the treatment of $100 \mathrm{~mL}$ of a $0.460 \mathrm{mM}$ tebuthiuron solution in $0.050 \mathrm{M} \mathrm{LiClO}_{4}$ with $0.50 \mathrm{mM} \mathrm{Fe}^{2+}$ at $\mathrm{pH}=3.0$ by EF with a BDD/air-diffusion cell at $j=100 \mathrm{~mA} \mathrm{~cm}^{-2}$ and $25^{\circ} \mathrm{C}$. 
Fig. $2 \mathrm{~b}$ and $\mathrm{c}$ depicts the evolution of the concentration of released $\mathrm{SO}_{4}{ }^{2-}$ and $\mathrm{NO}_{3}{ }^{-}$during the same EF treatment. $\mathrm{No} \mathrm{NO}_{2}{ }^{-}$ion was detected in the electrolyzed solution. Fig. $2 \mathrm{~b}$ highlights a continuous rise of $\mathrm{SO}_{4}{ }^{2-}$ ion content up to $0.460 \mathrm{mM}$, revealing that the $100 \%$ of the $\mathrm{S}$ of the herbicide was transformed into $\mathrm{SO}_{4}{ }^{2-}$ ion. Fig. $2 \mathrm{c}$ shows the increasing $\mathrm{NO}_{3}{ }^{-}$concentration with time, eventually reaching $0.701 \mathrm{mM}$ at $540 \mathrm{~min}$. At that time, the solution also contained $0.325 \mathrm{mM} \mathrm{NH}_{4}{ }^{+}$ion. These findings indicate that the soluble $\mathrm{TN}$ (see Fig. 2a) was predominantly in the form of $\mathrm{NO}_{3}{ }^{-}$rather than $\mathrm{NH}_{4}{ }^{+}$, accounting for $66.5 \%$ and $30.8 \%$, respectively. Consequently, a minor proportion of $2.7 \%$ of the initial $\mathrm{N}$ was present in the final solution as recalcitrant $N$-derivatives, probably being hydrocarbons since $5.5 \%$ of initial TOC was not mineralized yet.

From the aforementioned results, the theoretical total mineralization of TBH considering the formation of $\mathrm{SO}_{4}{ }^{2-}$ and $\mathrm{NO}_{3}{ }^{-}$as pre-eminent ions can be written a follows:

$$
\begin{aligned}
& \mathrm{C}_{9} \mathrm{H}_{16} \mathrm{~N}_{4} \mathrm{OS}+33 \mathrm{H}_{2} \mathrm{O} \rightarrow 9 \mathrm{CO}_{2}+4 \mathrm{NO}_{3}{ }^{-}+\mathrm{SO}_{4}{ }^{2-}+82 \mathrm{H}^{+}+ \\
& \text {- }
\end{aligned}
$$

For each trial, the MCE value (in \%) at current $I$ (in A) and electrolysis time $t$ (in $\mathrm{h}$ ) was then estimated from the TOC decay $(\triangle(\mathrm{TOC})$, in $\mathrm{mg} \mathrm{L}^{-1}$ ) via reaction (7) (Thiam et al., 2015a; Steter et al., 2016):

$$
\% \mathrm{MCE}=\frac{n F V \Delta(\text { TOC })}{4.32 \times 10^{7} \mathrm{mIt}} \times 100
$$

where $F$ is the Faraday constant, $V$ is the solution volume (in L), $4.32 \times 10^{7}$ is a conversion factor $\left(=3600 \mathrm{sh}^{-1} \times 12,000 \mathrm{mg} \mathrm{C} \mathrm{mol}^{-1}\right)$ and $m=9$ is the number of carbon atoms of TBH.

Fig. 1c presents the time course of MCE calculated from Eq. (7) for the assays of Fig. 1b. Low MCE values were always obtained due to both, the large recalcitrance of TBH (free or complexed) and its by-products and the high applied $j=100 \mathrm{~mA} \mathrm{~cm}^{-2}$. The efficiency increased upon upgrade of the oxidation ability of the treatment. In the most efficient processes (EF and PEF), the MCE gradually decayed from about 6.5 to $7.0 \%$ to near 3.4-3.5\%. A similar final value was determined in $\mathrm{AO}-\mathrm{H}_{2} \mathrm{O}_{2}$ (see Table 1), as expected from the close TOC abatement of about $91 \%$. The gradual decay of MCE with electrolysis time, which can be observed in Fig. 1c, is related to the progressive loss of organic load with formation of more recalcitrant species (Brillas et al., 2009; Panizza and Cerisola, 2009). All these findings confirm the main role of physisorbed BDD $\left({ }^{\circ} \mathrm{OH}\right)$ to cause the mineralization of free and complexed herbicide, with comparatively smaller contribution of ${ }^{\bullet} \mathrm{OH}$ in Fenton-based EAOPs and with null effect of UVA light in PEF.

\subsection{Effect of $\mathrm{Fe}^{2+}$ and herbicide concentrations on EF with BDD}

To gain a better insight into the chelating influence of the thiadiazole ring, the effect of $\mathrm{Fe}^{2+}$ and $\mathrm{TBH}$ concentrations on the performance of $\mathrm{EF}$ using the BDD/air-diffusion cell was investigated. Fig. 3 illustrates the results obtained with a $0.460 \mathrm{mM}$ herbicide solution at $\mathrm{pH} 3.0$ when the catalyst content varied between 0.10 and $1.50 \mathrm{mM}$. Fig. 3a shows an enhancement of TBH decay at a higher initial amount of catalyst, needing $360 \mathrm{~min}$ at $0.10 \mathrm{mM} \mathrm{Fe}^{2+}$ and only $180 \mathrm{~min}$ at $1.00 \mathrm{mM}$ and $1.50 \mathrm{mM} \mathrm{Fe}^{2+}$, for complete disappearance. This behavior is strongly determined by the herbicide abatement occurring within the first region until 3 min as maximal, since it clearly
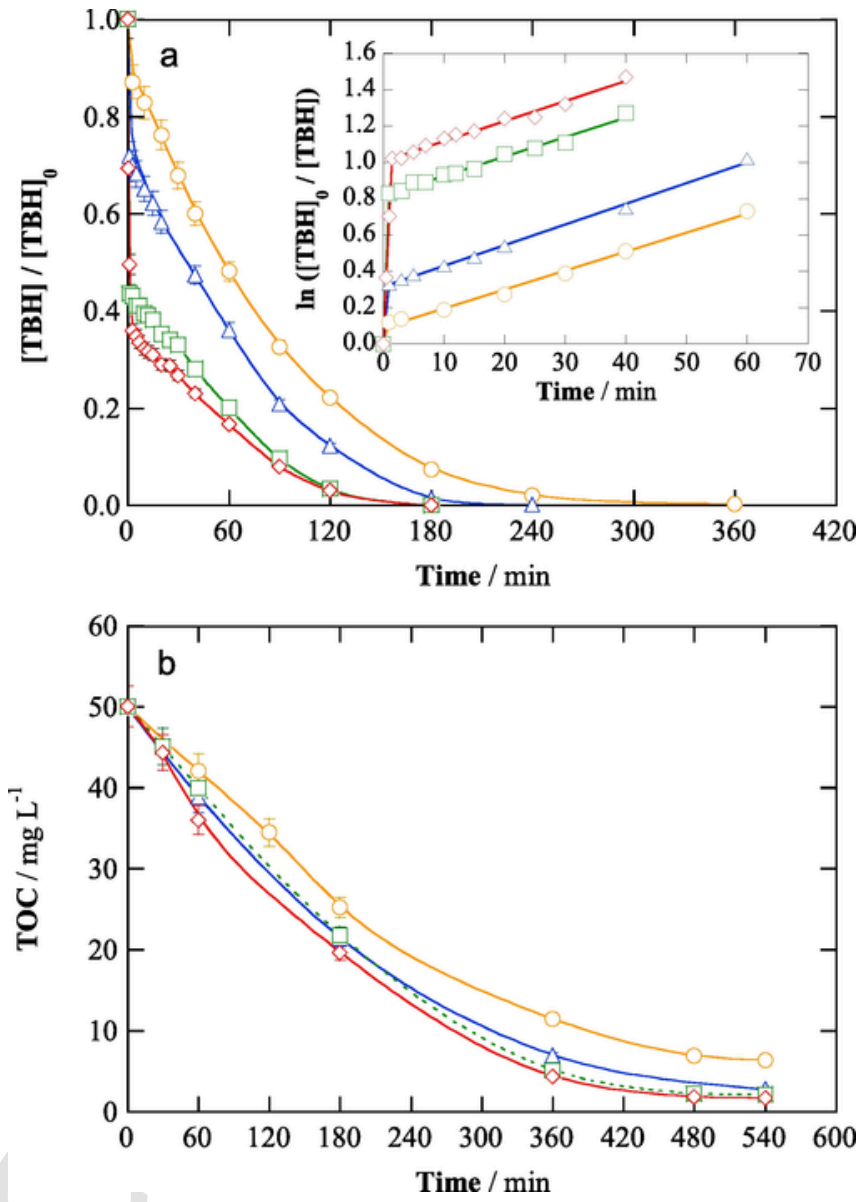

Fig. 3. Effect of $\mathrm{Fe}^{2+}$ concentration on (a) normalized tebuthiuron concentration abatement, along with the kinetic analysis considering a pseudo-first-order reaction, and (b) TOC decay vs. electrolysis time. Conditions: $100 \mathrm{~mL}$ of $0.460 \mathrm{mM}$ herbicide solutions in $0.050 \mathrm{M} \mathrm{Na}_{2} \mathrm{SO}_{4}$ at $\mathrm{pH}=3.0$ treated by $\mathrm{EF}$ using a $\mathrm{BDD} /$ air-diffusion cell at $j=100 \mathrm{~mA} \mathrm{~cm}^{-2}$ and $25^{\circ} \mathrm{C}$. [ $\left.\mathrm{Fe}^{2+}\right]$ : (○) $0.10 \mathrm{mM},(\bigwedge) 0.50 \mathrm{mM},(\square) 1.00 \mathrm{mM}$ and ( ๑) $1.50 \mathrm{mM}$

increased from about $10 \%$ to near $35 \%$ when changing from 0.10 to $1.00-1.50 \mathrm{mM} \mathrm{Fe}{ }^{2+}$. This tendency is corroborated by the pseudo-first-order kinetic analysis of both regions presented in the inset of Fig. 3a. In the first region, a progressive rise of $k_{1}$-value was found at higher $\mathrm{Fe}^{2+}$ content up to $1.00 \mathrm{mM}$, being 2.75 -fold and 6.67-6.92-fold higher at 0.50 and $1.00-1.50 \mathrm{mM}$, respectively, as compared to $0.10 \mathrm{mM}$ (see Table 1 ). In contrast, a mean $k_{1}$-value $\sim 1.1 \times 10^{-2} \mathrm{~min}^{-1}$ was found in the second region regardless of the amount of $\mathrm{Fe}^{2+}$ catalyst (see Table 1). These findings can be explained by the significant acceleration of ${ }^{-} \mathrm{OH}$ production from Fenton's reaction (3) as $\mathrm{Fe}^{2+}$ content grew, thus causing a quicker destruction of free $\mathrm{TBH}$ within the first region. However, no further upgrading was achieved from $1.00 \mathrm{mM} \mathrm{Fe}^{2+}$ because the excess of catalyst was detrimental as it partially destroyed the ${ }^{\circ} \mathrm{OH}$ from reaction (8) (Sirés et al., 2014; Moreira et al., 2017).

$$
\mathrm{Fe}^{2+}+\cdot \mathrm{OH} \rightarrow \mathrm{Fe}^{3+}+\mathrm{OH}^{-}
$$

Once the initial $\mathrm{Fe}^{2+}$ was quantitatively transformed into $\mathrm{Fe}^{3+}$, two key facts explain the deceleration of the $\mathrm{TBH}$ degradation: (i) the lower amount of $\mathrm{Fe}^{2+}$, which led to a smaller accumulation of $\bullet \mathrm{OH}$ from Fenton's reaction (3), and (ii) the presence of complexed TBH 
as predominant form of the herbicide. Therefore, this refractory species is oxidized within the second region preferentially upon the action of BDD $\left({ }^{*} \mathrm{OH}\right)$, as suggested by the similar $k_{1}$-value found at all $\mathrm{Fe}^{2+}$ contents. Nevertheless, the contribution of free ${ }^{\bullet} \mathrm{OH}$ is more significant in the mineralization process. This can be seen in Fig. 3b, where a slightly slower TOC decay occurred at $0.10 \mathrm{mM} \mathrm{Fe}^{2+}$, attaining $87.2 \%$ TOC removal after $540 \mathrm{~min}$, being smaller than $~ 94 \%$ obtained at $0.50-1.50 \mathrm{mM} \mathrm{Fe}^{2+}$ (see Table 1) because very low amounts of ${ }^{\bullet} \mathrm{OH}$ were produced at the lowest concentration of catalyst.

The degradation of $0.092-0.460 \mathrm{mM}$ herbicide solutions with $0.50 \mathrm{mM} \mathrm{Fe}^{2+}$ was assessed in the BDD/air-diffusion cell to examine the influence of TBH content on the EF treatment. Fig. 4a shows a clear acceleration of the free herbicide decrease within the first region as its content diminished, being as high as $80 \%$ at $0.092 \mathrm{mM}$ TBH. Total disappearance was achieved at $90 \mathrm{~min}$ for that solution, whereas it required $240 \mathrm{~min}$ for $0.460 \mathrm{mM}$, simply due to the presence of greater organic matter content. From the inset of this figure, the $k_{1}$-value was 3.94-fold and 2.82-fold greater for 0.092 and $0.184 \mathrm{mM}$, respectively, as compared to that found for $0.460 \mathrm{mM}$ (see Table 1). This trend can be related to the larger competition, between free TBH and its by-products to react with ${ }^{\circ} \mathrm{OH}$ formed from Fenton's reaction (3), as the herbicide concentration increased. This fact also affects the $k_{1}$-value in the second region, which decayed from $2.1 \times 10^{-3}$ to $1.1 \times 10^{-3} \mathrm{~min}^{-1}$ when the herbicide content was raised from 0.092 to $0.460 \mathrm{mM}$. A similar behavior is shown in Fig. $4 \mathrm{~b}$ for TOC removal, needing a longer time to reach a large mineralization at higher herbicide content, as a result of the slower oxidation of greater organic load. Conversely, Fig. $4 \mathrm{c}$ and Table 1 evidence that the MCE increased as the herbicide concentration was raised. This behavior is characteristic of the EAOPs, and results from the minimization of the parasitic (non-oxidizing) reactions of $\mathrm{BDD}\left({ }^{\bullet} \mathrm{OH}\right)$ and ${ }^{\bullet} \mathrm{OH}$, favoring the number of successful events and making the process more efficient (Sirés et al., 2014).

\subsection{Detection of oxidation intermediates and proposal of a degradation route}

Treatments of $0.460 \mathrm{mM}$ TBH (1) solutions for $4-5 \mathrm{~min}$ by AO- $\mathrm{H}_{2} \mathrm{O}_{2}, \mathrm{EF}$ and PEF with a BDD/air-diffusion cell allowed the identification of 8 heteroaromatic by-products preserving the thiadiazole ring along with 1,3-dimethylurea formed from its cleavage. Note that this short time was enough to ensure that, in the Fenton-based EAOPs, the herbicide was pre-eminently in the form of Fe(III)-TBH. The same oxidation by-products were found regardless of the EAOP tested, revealing an analogous reactivity of free and complexed TBH with the oxidizing agents. Fig. 5 shows the proposed reaction sequence for the initial destruction of the herbicide taking into account all the detected by-products. The main oxidant was the physisorbed $\mathrm{BDD}\left({ }^{\bullet} \mathrm{OH}\right)$ in $\mathrm{AO}-\mathrm{H}_{2} \mathrm{O}_{2}$ and, additionally, the homogeneous ${ }^{\bullet} \mathrm{OH}$ in $\mathrm{EF}$ and PEF, although all of them are depicted as ${ }^{\circ} \mathrm{OH}$ in Fig. 5 for the sake of simplification. A much slower degradation by other ROS $\left(\mathrm{H}_{2} \mathrm{O}_{2}, \mathrm{HO}_{2}^{*}\right)$ is also feasible, as pointed out above.

The path is initiated by the hydroxylation of $\mathrm{N}(3)$ of the 1,3-dimethylurea group of 1 with $\mathrm{m} / \mathrm{z} 228$ to yield $\mathbf{2}$ with $\mathrm{m} / \mathrm{z} 244$, which is subsequently oxidized to its aldehyde derivative 3 with $\mathrm{m} / z 242$. This compound can then undergo: (i) oxidation of the methyl substituent of $\mathrm{N}$ (1) to aldehyde yielding product 4 with $\mathrm{m} / \mathrm{z} 256$, (ii) cleavage of the $\mathrm{N}(1)-\mathrm{C}$ (2) bond of the lateral group to form compound 6 with $\mathrm{m} / \mathrm{z} 171$ and (iii) oxidation of the methyl substituent of $\mathrm{N}$ (1) to alcohol, along with scission of the N (3)-C (4) bond of the lateral group, originating the derivative 5 with $\mathrm{m} / \mathrm{z} 230$. Subsequent demethylation of $\mathbf{6}$ leads to compound 7 with $\mathrm{m} / \mathrm{z} 157$, which is then
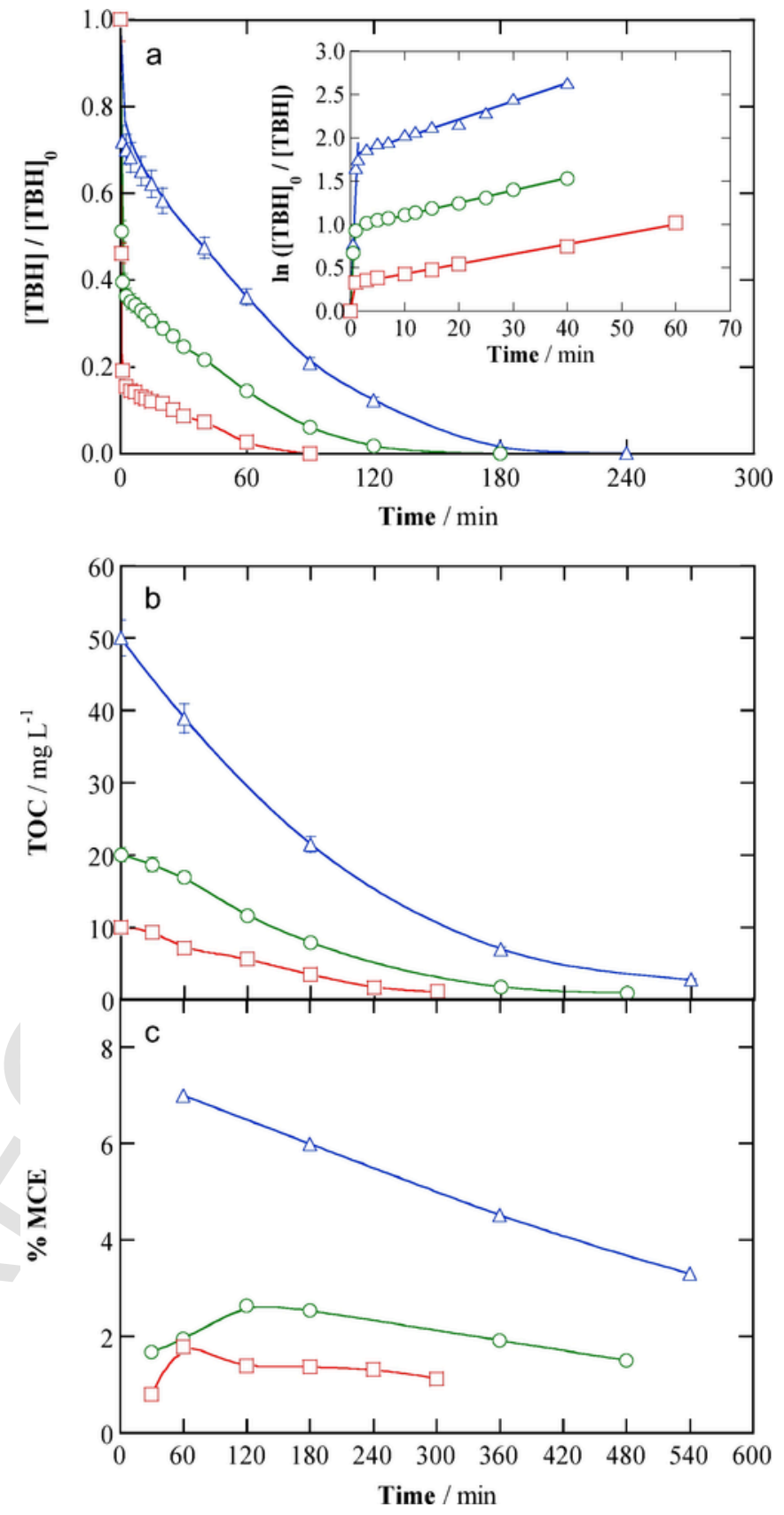

Fig. 4. (a) Normalized herbicide concentration removal, (b) TOC abatement and (c) change of mineralization current efficiency with electrolysis time for the treatment of $100 \mathrm{~mL}$ of $(\square) 0.092 \mathrm{mM}$, $(\bigcirc) 0.184 \mathrm{mM}$ and $(\triangle) 0.46 \mathrm{mM}$ tebuthiuron solutions in $0.050 \mathrm{M} \mathrm{Na}_{2} \mathrm{SO}_{4}$ with $0.50 \mathrm{mM} \mathrm{Fe}{ }^{2+}$ at $\mathrm{pH}=3.0$ by EF with a BDD/air-diffusion cell at $j=100 \mathrm{~mA} \mathrm{~cm}^{-2}$ and $25^{\circ} \mathrm{C}$. The corresponding pseudo-first-order kinetic analysis of decays shown in (a) is presented in the inset panel.

hydroxylated on the tert-butyl group to form product 8 with $\mathrm{m} / \mathrm{z} 173$ or deaminated to form the derivative 9 with $\mathrm{m} / \mathrm{z}$ 142. This latter product can also arise from the initial cleavage of 1 with release of 1,3-dimethylurea (compound 10) with $m / z 88$.

\subsection{THB degradation by EAOPs with Pt}

To better clarify the role of the different hydroxyl radicals, the study of TBH degradation was extended to a Pt/air-diffusion cell, 


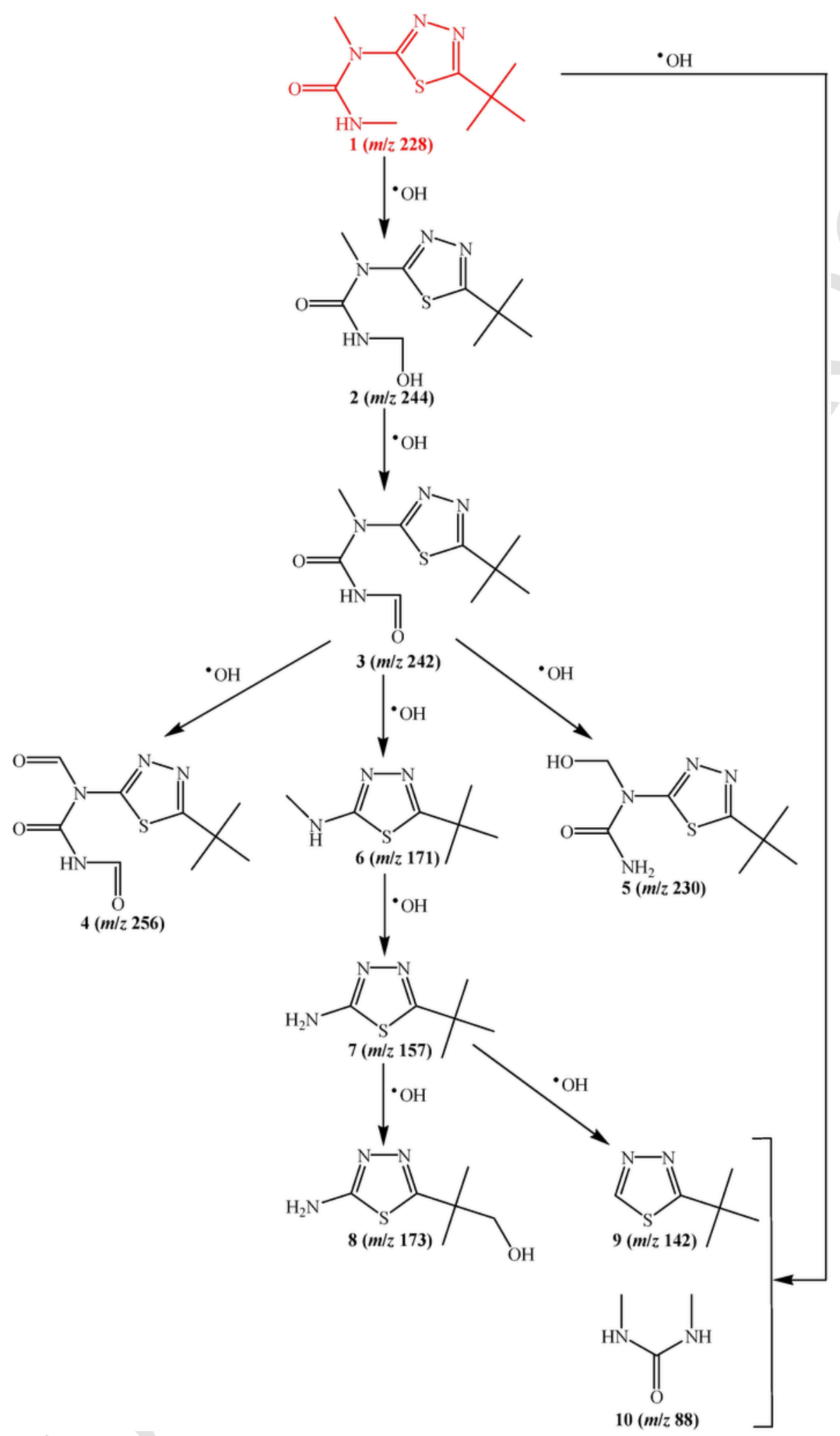

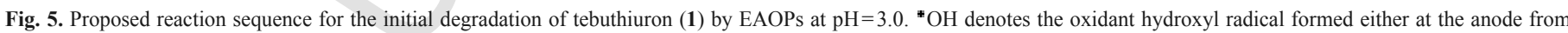
water oxidation or generated in the bulk from Fenton's reaction.

where a milder oxidation is expected owing to the active nature of $\mathrm{Pt}$ (Panizza and Cerisola, 2009; El-Ghenymy et al., 2014). This is confirmed from the results of Fig. 6, obtained for $0.460 \mathrm{mM}$ TBH solu- tions at $j=100 \mathrm{mAcm}^{-2}$. The herbicide concentration decay in AO- $\mathrm{H}_{2} \mathrm{O}_{2}$ was slower using Pt, showing a $k_{1}$-value 0.42 -fold lower as compared with BDD (see Fig. 6a and Table 1). Moreover, Fig. 6b re- 


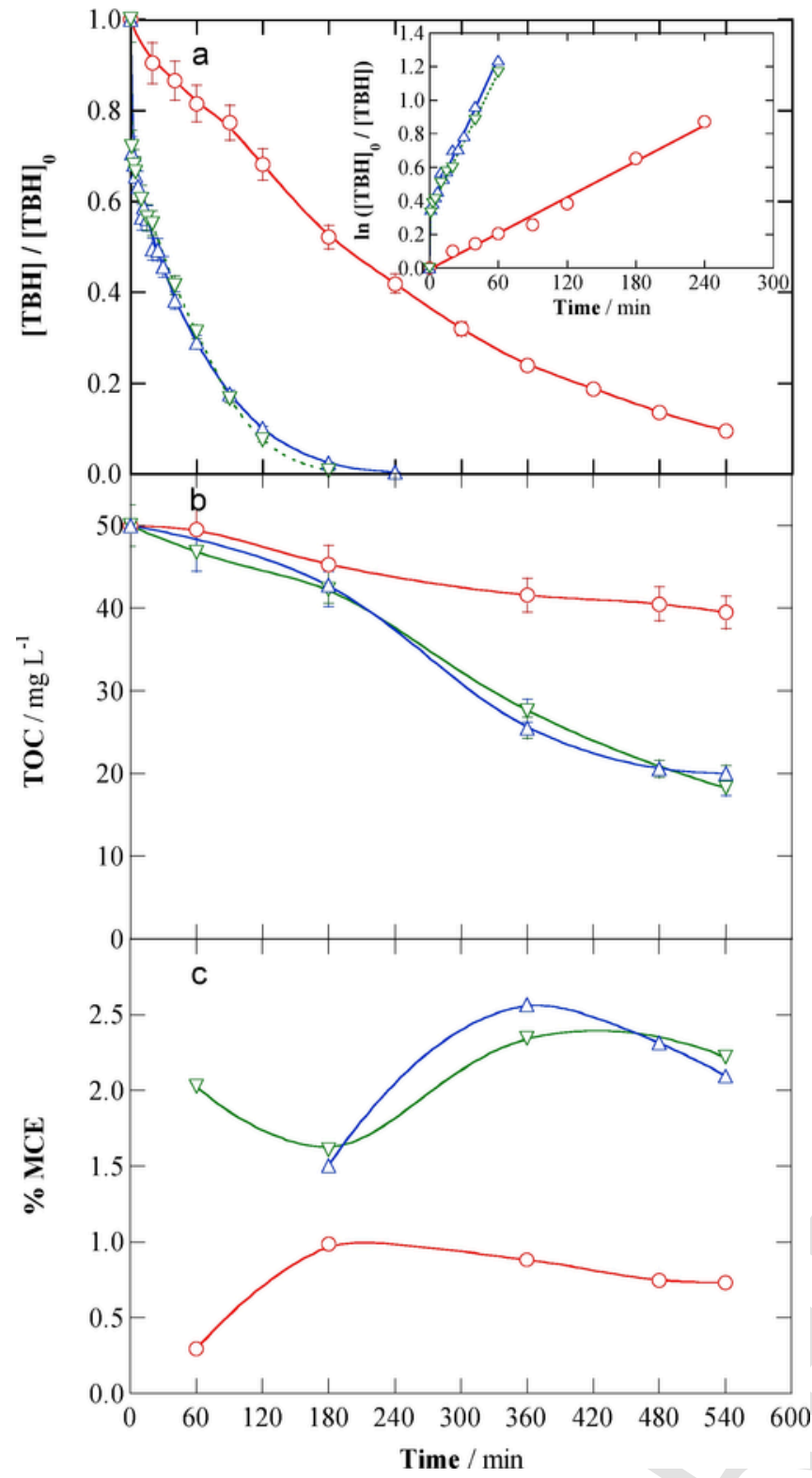

Fig. 6. Variation of (a) normalized tebuthiuron concentration, along with the pseudo-first-order kinetic analysis in the inset, (b) TOC and (c) mineralization current efficiency with electrolysis time for the treatment of $100 \mathrm{~mL}$ of $0.460 \mathrm{mM}$ herbicide solutions in $0.050 \mathrm{M} \mathrm{Na}_{2} \mathrm{SO}_{4}$ at $\mathrm{pH}=3.0$ with a stirred Pt/air-diffusion cell at $j=100 \mathrm{~mA} \mathrm{~cm}^{-2}$ and $25^{\circ} \mathrm{C}$. Method: (O) $\mathrm{AO}-\mathrm{H}_{2} \mathrm{O}_{2}$, (\) $\mathrm{EF}$ with $0.50 \mathrm{mM} \mathrm{Fe}^{2+}$ and ( V) PEF with $0.50 \mathrm{mM} \mathrm{Fe}^{2+}$ under illumination with a $6 \mathrm{~W}$ UVA lamp.

veals a very poor TOC removal, only attaining $21 \%$ mineralization (see Table 1), yielding MCE values $<1 \%$ (see Fig. 6c). From these findings, one can conclude that TBH is much more largely destroyed and mineralized by the more powerful BDD anode due to the much greater oxidation power of $\operatorname{BDD}\left(\bullet^{\circ} \mathrm{OH}\right)$ compared to $\mathrm{Pt}\left({ }^{\circ} \mathrm{OH}\right)$.

In contrast, small differences for TBH decay were obtained in $\mathrm{EF}$ and PEF with both anodes. Fig. 6a shows similar removal rates for both treatments, with total disappearance of the herbicide at $240 \mathrm{~min}$, as in the cell with BDD (see Fig. 1a). Table 1 summarizes analogous $k_{1}$-values within the first region regardless of the anode, corroborating the pre-eminent oxidation of TBH with free ${ }^{\circ} \mathrm{OH}$ under these conditions. In the second region, at times $>2-3 \mathrm{~min}$, slightly higher $k_{1}$-values were obtained for Pt (Table 1). This means that the complexed
TBH is more effectively oxidized by $\mathrm{Pt}\left({ }^{\bullet} \mathrm{OH}\right)$, probably because of its larger adsorption on $\mathrm{Pt}$ that favors the attack of heterogeneous hydroxyl radicals (Coria et al., 2016; Steter et al., 2016). Fig. 6b highlights that the TOC of the herbicide solution decayed in a similar way for EF and PEF with Pt, only being reduced by ca. $60-63 \%$ at $540 \mathrm{~min}$, being accompanied by small MCE values (see Fig. 6c). Therefore, intermediates were slowly destroyed by $\mathrm{Pt}\left({ }^{\bullet} \mathrm{OH}\right)$ and ${ }^{\bullet} \mathrm{OH}$, but much more rapidly and efficiently mineralized by $\operatorname{BDD}\left({ }^{\bullet} \mathrm{OH}\right)$ when using BDD.

Table 1 collects the results obtained in EF with $\mathrm{Pt}$ when the $\mathrm{Fe}^{2+}$ content of the $0.460 \mathrm{mM}$ herbicide solution grew up to 1.00 and $1.50 \mathrm{mM}$. As can be seen, the $k_{1}$-value within the first region was upgraded due to the quicker removal of free TBH by the larger amounts of $\bullet \mathrm{OH}$ formed from Fenton's reaction (3). The analogous $k_{1}$-values found in the second region regardless of the $\mathrm{Fe}^{2+}$ content confirms the preferential oxidation of Fe(III)-TBH by $\mathrm{Pt}\left({ }^{\bullet} \mathrm{OH}\right)$. Regarding the mineralization process, TOC abatement was accelerated as the catalyst content was raised, indicating that intermediates were more rapidly destroyed upon the action of ${ }^{\bullet} \mathrm{OH}$ rather than $\mathrm{Pt}\left({ }^{\bullet} \mathrm{OH}\right)$. However, only near $74 \%$ mineralization was achieved at the highest $\mathrm{Fe}^{2+}$ concentration, which is much less than $96.6 \%$ reached with BDD (see Table 1).

\section{Conclusions}

Acidic TBH solutions were mineralized more rapidly by $\mathrm{AO}-\mathrm{H}_{2} \mathrm{O}_{2}$, $\mathrm{EF}$ and $\mathrm{PEF}$ with a BDD/air-diffusion cell than using a $\mathrm{Pt}$ as the anode due to the higher oxidation power of $\operatorname{BDD}\left({ }^{\bullet} \mathrm{OH}\right)$ compared to $\mathrm{Pt}$ $\left({ }^{\bullet} \mathrm{OH}\right)$. In both kinds of cells, Fenton-based EAOPs were more effective because of the synergistic action of $\bullet^{\bullet} \mathrm{OH}$ formed from Fenton's reaction and physisorbed $\mathrm{M}\left({ }^{\bullet} \mathrm{OH}\right)$. The $\mathrm{S}$ and $\mathrm{N}$ atoms of the herbicide were pre-eminently released as $\mathrm{SO}_{4}{ }^{2-}$ and $\mathrm{NO}_{3}{ }^{-}$ions. Two consecutive kinetic regimes were found in $\mathrm{EF}$ and PEF, the first one related to the oxidation of free $\mathrm{TBH}$ by ${ }^{\bullet} \mathrm{OH}$, being quicker than the second stage that corresponded to the degradation of Fe(III)-TBH complex by $\mathrm{M}\left({ }^{\bullet} \mathrm{OH}\right)$. The increase of $\mathrm{Fe}^{2+}$ content and decrease of TBH concentration yielded a higher $k_{1}$-value within the first region because of the quicker ${ }^{\bullet} \mathrm{OH}$ production. In contrast, these two variables did not show substantial effect on the $k_{1}$-value in the second region since the complexed TBH was always oxidized by a similar amount of $\mathrm{M}\left({ }^{\bullet} \mathrm{OH}\right)$. Almost total mineralization with $>94 \%$ TOC removal was achieved by $\mathrm{EF}$ and PEF with BDD. The mineralization rate of both processes was similar because intermediates were not photoactive under UVA irradiation. A route for the initial TBH degradation is proposed from the 9 products detected by GC-MS.

\section{Acknowledgements}

The authors thank financial support from project CTQ2016-8616-R (AEI/FEDER, EU) and the Brazilian funding agencies Fundação de Apoio ao Desenvolvimento do Ensino, Ciência e Tecnologia do Estado de Mato Grosso do Sul (FUNDECT-MS), Pró-Reitoria de Pesquisa e Pós-Graduação da Universidade Federal de Mato Grosso do Sul (PROPP-UFMS), Coordenação de Aperfeiçoamento de Pessoal de Nível Superior, and Conselho Nacional de Desenvolvimento Científico e Tecnológico.

\section{References}

Alves, S.A., Ferreira, T.C.R., Lanza, M.R.V., 2012a. Electrochemical oxidation of the herbicide tebuthiuron using DSA ${ }^{\circledR}$-type electrode. Quim. Nova 35, 1981-1984.

Alves, S.A., Ferreira, T.C.R., Sabatini, N.S., Trientini, A.C.A., Migliorini, F.L., Baldan, M.R., Ferreira, N.G., Lanza, M.R.V., 2012b. Comparative study of the elec- 
trochemical oxidation of the herbicide tebuthiuron using boron-doped diamond electrodes. Chemosphere 88, 155-160.

Bahnemann, W., Muneer, M., Haque, M.M., 2007. Titanium dioxide-mediated photocatalysed degradation of few selected organic pollutants in aqueous suspensions. Catal. Today 124, 133-148.

Bolleter, W.T., Bushman, C.J., Tidwell, P.W., 1961. Spectrophotometric determination of ammonia as indophenol. Anal. Chem. 33, 592-594

Boye, B., Michaud, P.A., Marselli, B., Dieng, M.M., Brillas, E., Comninellis, C., 2002 Anodic oxidation of 4-chlorophenoxyacetic acid on synthetic boron-doped diamond electrodes. N. Diamond Front. Carbon Technol. 12, 63-72.

Brillas, E., Sirés, I., Oturan, M.A., 2009. Electro-Fenton and related electrochemical technologies based on Fenton's reaction chemistry. Chem. Rev. 109, 6570-6631

Cañizares, P., Lobato, J., Paz, R., Rodrigo, M.A., Saez, C., 2005. Electrochemical oxidation of phenolic compound wastes with BDD anodes. Water Res. 39, 2687-2703.

Chiron, S.A.R., Fernandez-Alba, A.R., Rodriguez, A., Garcia-Calvo, E., 2000. Pesticide chemical oxidation: state-of-the-art. Water Res. 34, 366-377.

Coria, G., Pérez, T., Sirés, I., Nava, J.L., 2015. Mass transport studies during dissolved oxygen reduction to hydrogen peroxide in a filter-press electrolyzer using graphite felt, reticulated vitreous carbon and boron-doped diamond as cathodes. J. Electroanal. Chem. 757, 225-229.

Coria, G., Sirés, I., Brillas, E., Nava, J.L., 2016. Influence of the anode material on the degradation of naproxen by Fenton-based electrochemical processes. Chem. Eng. J. 304, 817-825.

Cruz-González, K., Torres-López, O., García-León, A., Brillas, E., Hernández-Ramírez, A., Peralta-Hernández, J.M., 2012. Optimization of electro-Fenton/BDD process for decolorization of a model azo dye wastewater by means of response surface methodology. Desalination 286, 63-68.

Diaz, L., Llorca-Porcel, J., Valor, I., 2008. Ultra trace determination of 31 pesticides in water samples by direct injection-rapid resolution liquid chromatography-electrospray tandem mass spectrometry. Anal. Chim. Acta 624, 90-96.

Dirany, A., Sirés, I., Oturan, N., Özcan, A., Oturan, M.A., 2012. Electrochemical treatment of the antibiotic sulfachloropyridazine: kinetics, reaction pathways, and toxicity evolution. Environ. Sci. Technol. 46, 4074-4082.

dos Santos, E.V., Sáez, C., Martínez-Huitle, C.A., Cañizares, P., Rodrigo, M.A., 2015. The role of particle size on the conductive diamond electrochemical oxidation of soil-washing effluent polluted with atrazine. Electrochem. Commun. 55, 26-29.

El-Ghenymy, A., Garrido, J.A., Rodríguez, R.M., Cabot, P.L., Centellas, F., Arias, C., Brillas, E., 2013. Degradation of sulfanilamide in acidic medium by anodic oxidation with a boron-doped diamond anode. J. Electroanal. Chem. 689, 149-157.

El-Ghenymy, A., Rodríguez, R.M., Brillas, E., Oturan, N., Oturan, M.A., 2014. Electro-Fenton degradation of the antibiotic sulfanilamide with $\mathrm{Pt} /$ carbon-felt and BDD/carbon-felt cells. Kinetics, reaction intermediates, and toxicity assessment Environ. Sci. Pollut. Res. 21, 8368-8378.

Ferracini, V.L., Queiroz, S.C.N., Santos, M.A.F., Gomes, G.L., 2005. Method for determination of hexazinone and tebuthiuron in water. Quim. Nova 28, 380-382.

Guelfi, D.R.V., Gozzi, F., Machulek Jr., A., Sirés, I., Brillas, E., de Oliveira, S.C., 2018. Degradation of herbicide S-metolachlor by electrochemical AOPs using a boron-doped diamond anode. Catal. Today https://doi.org/10.1016/j.cattod.2017. 10.026, (in press).

Guelfi, D.R.V., Gozzi, F., Sirés, I., Brillas, E., Machulek Jr., A., de Oliveira, S.C., 2017. Degradation of the insecticide propoxur by electrochemical oxidation processes using a boron-doped diamond/air-diffusion cell. Environ. Sci. Pollut. Res. 24, 6083-6095.

Khataee, A., Akbarpour, A., Vahi, B., 2014. Photoassisted electrochemical degradation of an azo dye using $\mathrm{Ti} / \mathrm{RuO}_{2}$ anode and carbon nanotubes containing gas-diffusion cathode. J. Taiwan Inst. Chem. Eng. 45, 930-936.

Khataee, A., Khataee, A., Fathinia, M., Vahid, B., Joo, S.W., 2013. Kinetic modeling of photoassisted-electrochemical process for degradation of an azo dye using boron-doped diamond anode and cathode with carbon nanotubes. J. Ind. Eng. Chem. 19, 1890-1894.
Lanzalaco, S., Sirés, I., Sabatino, M.A., Dispenza, C., Scialdone, O., Galia, A., 2017. Synthesis of polymer nanogels by electro-Fenton process: investigation of the effect of main operation parameters. Electrochim. Acta 246, 812-822.

Lourencetti, C., Rodrigues de Marchi, M.R., Ribeiro, M.L., 2008. Determination of sugar cane herbicides in soil and soil treated with sugar cane vinasse by solid-phase extraction and HPLC-UV. Talanta 77, 701-709.

Marselli, B., Garcia-Gomez, J., Michaud, P.A., Rodrigo, M.A., Comninellis, C., 2003. Electrogeneration of hydroxyl radicals on boron-doped diamond electrodes. J. Electrochem. Soc. 150, D79-D83.

Martínez-Huitle, C.A., Rodrigo, M.A., Sirés, I., Scialdone, O., 2015. Single and coupled electrochemical processes and reactors for the abatement of organic water pollutants: a critical review. Chem. Rev. 115, 13362-13407.

Moreira, F.C., Boaventura, R.A.R., Brillas, E., Vilar, V.J.P., 2017. Electrochemical advanced oxidation processes: a review on their application to synthetic and real wastewaters. Appl. Catal. B Environ. 202, 217-261.

Muneer, M., Qamar, M., Saquib, M., Bahnemann, D.W., 2005. Heterogeneous photocatalysed reaction of three selected pesticide derivatives, propham, propachlor and tebuthiuron in aqueous suspensions of titanium dioxide. Chemosphere 61, $457-468$.

Nogueira, R.F.P., Silva, M.R.A., Trovó, A.G., 2005. Influence of the iron source on the solar photo-Fenton degradation of different classes of organic compounds. Sol. Energy $79,384-392$.

Oturan, N., Sirés, I., Oturan, M.A., Brillas, E., 2009. Degradation of pesticides in aqueous medium by electro-Fenton and related methods. A review. J. Environ. Eng. Manage 19, 235-255.

Özcan, A., Şahin, Y., Koparal, A.S., Oturan, M.A., 2008. Propham mineralization in aqueous medium by anodic oxidation using boron-doped diamond anode. Experimental parameters' influence on degradation kinetics and mineralization efficiency. Water Res. 42, 2889-2898.

Panizza, M., Cerisola, G., 2009. Direct and mediated anodic oxidation of organic pollutants. Chem. Rev. 109, 6541-6569.

Rodrigo, M.A., Oturan, N., Oturan, M.A., 2014. Electrochemically assisted remediation of pesticides in soils and water: a review. Chem. Rev. 114, 8720-8745.

Silva, M.R.A., Trovó, A.G., Nogueira, R.F.P., 2007. Degradation of the herbicide tebuthiuron using solar photo-Fenton process and ferric citrate complex at circumneutral pH. J. Photochem. Photobiol. Chem. 191, 187-192.

Silva, M.R.A., Vilegas, W., Zanoni, M.V.B., Nogueira, R.F.P., 2010. Photo-Fenton degradation of the herbicide tebuthiuron under solar irradiation: iron complexation and initial intermediates. Water Res. 44, 3745-3753.

Sirés, I., Brillas, E., 2012. Remediation of water pollution caused by pharmaceutical residues based on electrochemical separation and degradation technologies: a review. Environ. Int. 40, 212-229.

Sirés, I., Brillas, E., Oturan, M.A., Rodrigo, M.A., Panizza, M., 2014. Electrochemical advanced oxidation processes: today and tomorrow. A review. Environ. Sci. Pollut. Res. 21, 8336-8367.

Steter, J.R., Brillas, E., Sirés, I., 2016. On the selection of the anode material for the electrochemical removal of methylparaben from different aqueous media. Electrochim. Acta 222, 1464-1474.

Thiam, A., Brillas, E., Centellas, F., Cabot, P.L., Sirés, I., 2015a. Electrochemical reactivity of Ponceau 4R (food additive E124) in different electrolytes and batch cells. Electrochim. Acta 173, 523-533.

Thiam, A., Sirés, I., Garrido, J.A., Rodriguez, R.M., Brillas, E., 2015b. Effect of anions on electrochemical degradation of azo dye Carmoisine (Acid Red 14) using a BDD anode and air-diffusion cathode. Separ. Purif. Technol. 140, 41-52.

Vasudevan, S., Oturan, M.A., 2014. Electrochemistry: as cause and cure in water pollution-an overview. Environ. Chem. Lett. 12, 97-108.

Wang, A., Qu, J., Liu, H., Ru, J., 2008. Mineralization of an azo dye Acid Red 14 by photoelectro-Fenton process using an activated carbon fiber cathode. Appl. Catal B Environ. 84, 393-399. 